\title{
Antihepatotoxic effect of grape seed oil in rat
}

\author{
M. Uma Maheswari' ${ }^{1}$ P. G. M. Rao
}

\section{${ }^{1}$ College of Pharmacy, Sri Ramakrishna Institute of Paramedical Sciences, Coimbatore, Tamilnadu, India; \\ ${ }^{2}$ Department of} Pharmacology, College of Pharmaceutical Sciences, Manipal, Karnataka, India

Received: 14.8.2003

Revised: 5.7.2004

Accepted: 28.8.2004

Correspondence to: M. Uma Maheswari E-mail: muma_prakash@yahoo.com

\section{ABSTRACT}

Objectives: To study the effect of oral administration of grape seed oil (GSO) against carbontetrachloride $\left(\mathrm{CCl}_{4}\right)$-induced hepatotoxicity in rats.

Methods: Liver damage was induced in male Wistar rats (150-250 g) by administering $\mathrm{CCl}_{4}(0.5$ $\mathrm{ml} / \mathrm{kg}$, i.p.) once per day for 7 days and the extent of damage was studied by assessing biochemical parameters such as alanine aminotransferase (ALT), aspartate aminotransferase (AST), and alkaline phosphatase (ALP) in serum and concentrations of malondialdehyde (MDA), hydroperoxides, glutathione $(\mathrm{GSH})$, catalase (CAT), superoxide dismutase (SOD), and total protein (TP) in liver. The effect of co-administration of GSO $(3.7 \mathrm{~g} / \mathrm{kg}$, orally) on the above parameters was further investigated and compared with a vitamin E $(100 \mathrm{mg} / \mathrm{kg}$, orally) treated group. Histopatholgical studies of the experimental animals were also done.

Results: Oral administration of GSO $(3.7 \mathrm{~g} / \mathrm{kg}$, body weight orally) for 7 days resulted in a significant reduction in serum AST, ALT, and ALP levels and liver MDA and hydroperoxides and significant improvement in glutathione, SOD, CAT, and TP, when compared with $\mathrm{CCl}_{4}$ damaged rats. The antioxidant effect of GSO at $3.7 \mathrm{~g} / \mathrm{kg}$ for 7 days was found to be comparable with vitamin $\mathrm{E}$ (100 $\mathrm{mg} / \mathrm{kg}$, orally) in $\mathrm{CCl}_{4}$-treated rats. Profound fatty degeneration, fibrosis, and necrosis observed in the hepatic architecture of $\mathrm{CCl}_{4}$-treated rats were found to acquire near - normalcy in drug coadministered rats.

Conclusion: The GSO has protected the liver from $\mathrm{CCl}_{4}$ damage. Probable mechanism of action may be due to the protection against oxidative damage produced by $\mathrm{CCl}_{4}$.

KEY WORDS: Antihepatotoxic effect; glutathione; grape seed oil.
Grape seed oil (GSO) is obtained from grape seeds after the wine pressing in Italy and France. The GSO contains $75 \%$ linoleic acid, $15 \%$ oleic acid, $6 \%$ palmitic acid, 3\% stearic acid, and $1 \%$ linolenic acid. ${ }^{[1]}$ Studies revealed the beneficial HDL effect of GSO and research shows that subjects were instructed to use up to $45 \mathrm{ml}$ of GSO in their daily diet as a substitute for their usual oil and within 2 weeks there was 13-14\% increase in HDL level. ${ }^{[2]}$ The GSO has a very high level of antioxidant vitamin E (60-120 mg/100 g), which makes the oil very stable. The antioxidant property is claimed to be the mechanism of hepatoprotective activity. ${ }^{[3]}$ The GSO exhibits a variety of interesting properties such as reducing platelet aggregation, prevents hypertension caused by sodium excess, normalizes lesions occurring from obesity and diabetes. ${ }^{[4]}$

Among the various mechanisms involved in the hepatotoxic effect of carbontetrachloride $\left(\mathrm{CCl}_{4}\right)$, one is oxidative damage through free-radical generation ${ }^{[5]}$ and antioxidant property is claimed to be one of the mechanisms of hepatoprotective effect of indigenous drugs. ${ }^{[6]}$ The GSO has antioxidant properties. ${ }^{[2] \mid[3]}$ Hence, the objective of the study was to evaluate the effect of GSO on $\mathrm{CCl}_{4}$-induced hepatotoxicity.

\section{Materials and methods}

Drugs and chemicals

The GSO is a kind gift from LoDuca Bros Inc., Milwaukee,
USA. Carbontetrachloride $\left(\mathrm{CCl}_{4}\right)$ was obtained from E. Merck (India) Ltd., Mumbai. Thiobarbituric acid (TBA), 5,51-dithiobis-2-nitrobenzoic acid (DTNB), and glutathione (GSH) were obtained from Sigma, USA. Vitamin E was obtained from Hi Media Pvt., Ltd., Mumbai. All chemicals used in the study were of analytical grade.

\section{Experimental animals}

Male Wistar albino rats (150-250 g) were used. The animals were acclimatized to laboratory conditions for 5 days prior to the experiments and had access to food and water ad libitum. Before commencing the work, permission from Institutional Animal Ethics Committee was obtained.

\section{Selection of dose of GSO}

The human dose of GSO was converted in to the animal dose using the standard dose-converting table. ${ }^{[7]}$ Further, the dose for the hepatoprotective studies was adjusted based on the observation during the toxicity studies. The GSO at a dose of $3.7 \mathrm{~g} / \mathrm{kg}(4 \mathrm{ml} / \mathrm{kg})$ was administered orally to study the hepatoprotective activity. An emulsion of GSO was prepared using $2 \%$ gum acacia by wet gum method.

\section{Experimental design}

Acute toxicity studies

Wistar Albino rats (150-250 g) maintained under standard laboratory conditions were used. A total of five animals 
were used which received a single-oral dose (2000 mg/kg, body weight) of GSO. Animals were kept overnight fasting prior to drug administration. After the administration of GSO, food was with held for further 3-4 h. Animals were observed individually at least once during the first 30 min after dosing, periodically during the first $24 \mathrm{~h}$ (with special attention during the first $4 \mathrm{~h}$ ) and daily thereafter for a period of 14 days. Once daily cage side observations included changes in skin and fur, eyes and mucous membrane (nasal), and also respiratory rate, circulatory (heart rate and blood pressure), autonomic (salivation, lacrimation, perspiration, piloerection urinary incontinence, and defecation), and central nervous system (ptosis, drowsiness, gait, tremors and convulsion $)^{[8]}$ changes.

\section{Hepatoprotective studies}

Animals were divided into five groups, consisting of six animals each. Group I served as control, which received $2 \%$ gum acacia orally for 7 days. Group II received GSO $(3.7 \mathrm{~g} / \mathrm{kg}$, orally) for 7 days. Group III received $\mathrm{CCl}_{4} 0.5 \mathrm{ml} / \mathrm{kg}$, i.p. for 7 days. ${ }^{[9]-[11]}$ Group IV received $\mathrm{CCl}_{4} 0.5 \mathrm{ml} / \mathrm{kg}$, i.p. and GSO (3.7 $\mathrm{g} / \mathrm{kg}$, orally ) simultaneously for 7 days. Group V received $\mathrm{CC} 1_{4}$ $0.5 \mathrm{ml} / \mathrm{kg}$, i.p. and vitamin $\mathrm{E}(100 \mathrm{mg} / \mathrm{kg} \text {, orally })^{\lfloor 12\rfloor}$ simultaneously for 7 days. After 7 days of treatment, the rats were kept overnight fasting and killed by cervical dislocation. At the end of the treatment, blood samples were collected by direct cardiac puncture under ether anaesthesia and the serum was used for the assay of marker enzymes viz., aspartate aminotransferase (AST), alanine aminotransferase (ALT), and alkaline phosphatase (ALP). ${ }^{[13],[14]}$ The enzyme levels were assayed using the standard kits from Lupin laboratories. The results were expressed as units/liter (U/l). Liver samples were dissected out and washed immediately with ice-cold saline to remove as much blood as possible. Liver homogenates (5\% w/v) were prepared in cold $50 \mathrm{mM}$ potassium phosphate buffer (pH 7.4) using a Remi homogenizer. The unbroken cells and cell debris were removed by centrifugation at $1000 \mathrm{rpm}$ for 10 min using a Remi C-24 refrigerated centrifuge. The supernatant was used for the estimation of $\mathrm{GSH},{ }^{[15]}$ malondialdehyde (MDA), ${ }^{[16]}$ hydroperoxides, ${ }^{[17]}$ superoxide dismutase (SOD), ${ }^{[18]}$ catalase (CAT) $)^{[19]}$, and total protein (TP) ${ }^{[20]}$ levels.

\section{Histopathological studies}

A portion of liver tissue in each group was preserved in $10 \%$ formaldehyde solution for histopathological studies. Haematoxylin and eosin were used for staining and later the microscopic slides of the liver cells were photographed. ${ }^{[1],[22]}$ Statistical analysis

Values were represented as mean \pm SD. Data were analyzed using one-way analysis of variance (ANOVA) and group means were compared using Duncan's multiple range test. $\mathrm{P}$ values $<0.05$ were considered significant. ${ }^{23]}$

\section{Results}

In acute toxicity study, no signs, and symptoms of toxicity and mortality were observed. There was a significant $(\mathrm{P}<0.05)$ increase in the serum hepatic enzyme levels after $\mathrm{CCl}_{4}$ treatment, which was prevented with GSO. The GSO when administered alone did not alter the enzyme levels when compared to the control values. The MDA and hydroperoxide levels were found to be elevated after the administration of $\mathrm{CCl}_{4}$, which was significantly $(\mathrm{P}<0.05)$ prevented by GSO. There

\section{Table 1}

Effect of GSO on serum ALT, AST, and ALP in rats after 7 days treatment

\begin{tabular}{|c|c|c|c|}
\hline Groups & $A L T(U / I)$ & $A S T(U / I)$ & $A L P(U / I)$ \\
\hline $\begin{array}{l}\text { Control } \\
\text { (2\% gum acacia) }\end{array}$ & $71.3 \pm 4.3^{*}$ & $286.3 \pm 1.7^{*}$ & $1101.3 \pm 6.5^{\star}$ \\
\hline GSO (3.7 g/kg) & $79.9 \pm 5.7^{*}$ & $295.6 \pm 3.0^{*}$ & $1195.0 \pm 4.5^{*}$ \\
\hline $\mathrm{CCl}_{4}(0.5 \mathrm{ml} / \mathrm{kg}$, i.p. $)$ & $259.6 \pm 2.4^{* *}$ & $775.3 \pm 3.6^{* *}$ & $1569.4 \pm 3.6^{* *}$ \\
\hline $\mathrm{CCl}_{4}+\mathrm{GSO}(3.7 \mathrm{~g} / \mathrm{kg})$ & $91.3 \pm 1.3^{* * *}$ & $312.8 \pm 3.0^{\star \star *}$ & $1224.3 \pm 2.6^{\star \star *}$ \\
\hline $\mathrm{CCl}_{4}+\mathrm{VE}(100 \mathrm{mg} / \mathrm{kg})$ & $84.3 \pm 7.3^{*}, * * *$ & $301.3 \pm 3.4^{*}$, ,** & $1206.8 \pm 4.0^{*}, * * *$ \\
\hline$F$ & 58.3 & 117.9 & 245.9 \\
\hline d.f. & 4,25 & 4,25 & 4,25 \\
\hline$P$ & $<0.05$ & $<0.05$ & $<0.05$ \\
\hline
\end{tabular}

Values are mean ${ }_{ \pm} S D ; n=6$ in each group. Values with different superscripts $\left({ }^{*}, * \star\right.$ and $\left.{ }^{* * \star}\right)$ differ significantly from each other at $\mathrm{P}<0.05$ (Duncan's multiple range test).

was a significant $(\mathrm{P}<0.05)$ rise in GSH, SOD and CAT contents of liver after treatment with GSO. There was a significant decrease in TP level after $\mathrm{CCl}_{4}$ treatment, which was prevented with GSO (Table 1 and 2).

Histopathological examination

Histoathological examination of $\mathrm{CCl}_{4}$-treated rat liver revealed fatty degeneration, necrosis, and fibrosis (Fig. 1). Concurrent administration of GSO preserved the histological structure of liver though there was mild congestion and regeneration of liver tissue (Fig. 2).

\section{Discussion}

The $\mathrm{CCl}_{4}$ is one of the most commonly used hepatotoxins in the experimental study of liver diseases. ${ }^{[24]}$ The lipid peroxidative degradation of biomembranes is one of the principal causes of hepatotoxicity of $\mathrm{CCl}_{4}{ }^{\mid{ }^{[25]}}$ This is evidenced by an elevation in the serum maker enzymes, namely AST, ALT, and ALP. The GSO has significantly reduced these liver enzyme levels. Further, GSO has increased the level of TPs, which indicates hepatoprotective activity. Stimulation of protein synthesis accelerates the regeneration process and the production of liver cells.

In our study, elevation in the levels of end products of lipid peroxidation in $\mathrm{CCl}_{4}$-treated animals was observed. The increase in MDA and hydroperoxide levels in liver suggests enhanced lipid peroxidation leading to tissue damage and failure of antioxidant defence mechanisms. Treatment with GSO significantly prevented these changes. Hence, the mechanism of hepatoprotection of GSO may be due to its antioxidant effect. Since GSO has significantly increased the glutathione, SOD and CAT contents of the liver, it may also be useful in hepatotoxicity induced by other agents. The antioxidant enzyme levels of the $\mathrm{CCl}_{4}$-treated group were decreased whereas that of GSO-treated group is almost similar to that of the control and vitamin-E-treated groups.

Histopathological studies showed that $\mathrm{CCl}_{4}$ caused fatty degeneration and necrosis of the liver tissue. Pretreatment with GSO exhibited protection, which confirmed the results of 
Figure 1. Liver tissue of $\mathrm{CCl}_{4}$-treated animals showing fatty degeneration and necrosis (haematoxylin and eosin $x 100$ )

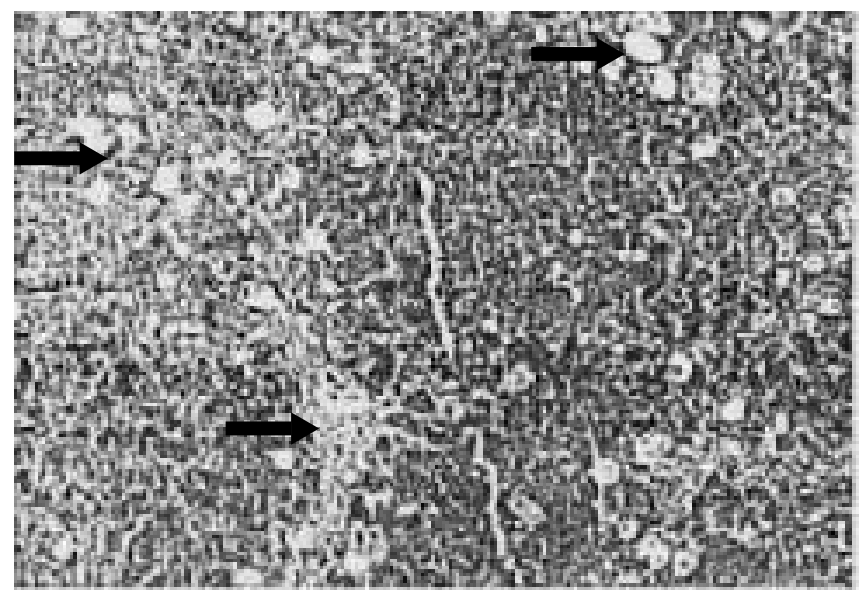

Figure 2. Liver tissue of rats treated with $\mathrm{CCl}_{4}$ and GSO showing almost normal histology and mild congestion (haematoxylin and eosin x 100)

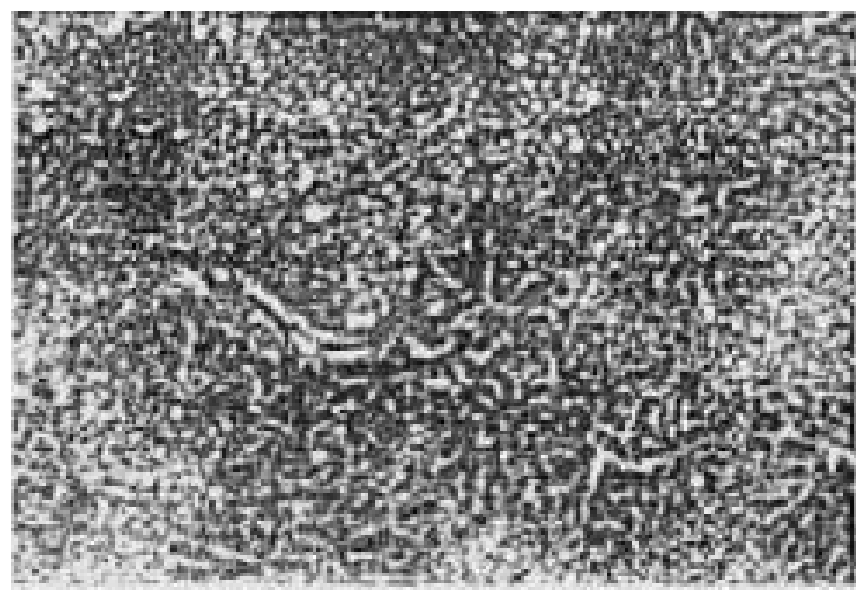

Table 2

\begin{tabular}{|c|c|c|c|c|c|c|}
\hline Groups & $\begin{array}{c}\text { MDA } \\
\text { nmol } / \mathrm{mg} \\
\text { protein }\end{array}$ & $\begin{array}{c}\text { Hydroperoxides } \\
\text { mmol/100 g } \\
\text { tissue }\end{array}$ & $\begin{array}{c}\text { GSH } \\
\mathrm{mg} / 100 \mathrm{~g} \\
\text { tissue }\end{array}$ & $\begin{array}{c}\text { SOD } \\
\text { units } / m g \\
\text { protein }\end{array}$ & $\begin{array}{c}\text { CAT } \\
\text { units } / m g \\
\text { protein }\end{array}$ & $\begin{array}{c}\text { Total } \\
\text { mg/mI } \\
\text { protein }\end{array}$ \\
\hline Control (2\% gum acacia) & $198.7 \pm 2.2^{*}$ & $72.3 \pm 3.1^{*}$ & $46.8 \pm 1.8^{*}$ & $6.80 \pm 0.25^{\star}$ & $75.2 \pm 1.46^{*}$ & $20.35 \pm 1.34^{*}$ \\
\hline GSO $(3.7 \mathrm{~g} / \mathrm{kg})$ & $220.5 \pm 5.7^{*}$ & $70.6 \pm 6.6^{*}$ & $44.0 \pm 2.2^{*}$ & $6.91 \pm 0.22^{*}$ & $76.7 \pm 1.13^{*}$ & $19.42 \pm 3.55^{\star}$ \\
\hline $\mathrm{CCl}_{4}(0.5 \mathrm{ml} / \mathrm{kg}$, i.p. $)$ & $461.1 \pm 4.0^{* *}$ & $97.6 \pm 5.3^{* *}$ & $20.8 \pm 5.1^{* *}$ & $3.41 \pm 0.09^{* *}$ & $44.9 \pm 1.30^{* *}$ & $9.10 \pm 0.70^{\star *}$ \\
\hline $\mathrm{CCl}_{4}+\mathrm{VE}(100 \mathrm{mg} / \mathrm{kg})$ & $236.3 \pm 1.4^{*}$ & $75.4 \pm 3.5^{*}$ & $41.3 \pm 4.1^{*}$ & $6.48 \pm 0.24^{*}$ & $69.9 \pm 3.10^{*}$ & $19.36 \pm 5.60^{*}$ \\
\hline$F$ & 81.9 & 12.4 & 22.4 & 4.67 & 11.12 & 3.47 \\
\hline d.f. & 4,25 & 4,25 & 4,25 & 4,25 & 4,25 & 4,25 \\
\hline$P$ & $<0.05$ & $<0.05$ & $<0.05$ & $<0.05$ & $<0.05$ & $<0.05$ \\
\hline
\end{tabular}

Values are mean $\pm S D ; n=6$ in each group. Values with different superscripts $\left({ }^{*}{ }^{* \star}\right.$ and $\left.{ }^{* \star *}\right)$ differ significantly from each other at $P<0.05$ (Duncan's multiple range test).

biochemical studies. These results of our study indicate that simultaneous treatment with GSO protects the liver against $\mathrm{CCl}_{4}$-induced hepatotoxicity.

The GSO offers vast possibilities in the treatment of various liver disorders. This may be due to the high level of antioxidant vitamin E, which was claimed to be the mechanism of hepatoprotection. Further studies on any other models and extensive clinical trials are needed to confirm these results.

\section{Acknowledgments}

The authors express their sincere gratitude to LoDuca Bros Inc., Milwaukee, USA, for their generous supply of Olitalia GSO.

\section{References}

1. Natella F, Belleli F, Gentili V, Ursini F, Scaccini C. Grape seed proanthocyanidins prevent plasma post prandial oxidative stress in humans. J Agric Food Chem 2002;26:7720-5.

2. Nash DT, Nash SD. Grapeseed oil, a natural agent which raises serum HDL levels. J Am Coll Cardiol 1993;21:318-20.

3. Bagchi D, Bagchi M, Stohs S, Ray SD, Sen CK, Preuss HG. Cellular protec- tion with proanthocyanidins derived from grape seeds. Ann NY Acad Sci 2002;957: 260-70.

4. Bagchi D, Ray SD, Bagchi M, Preuss HG, Stohs SJ. Mechanistic pathways of antioxidant cytoprotection by a novel IH 636 grape seed proanthocyanidin extract. Indian J Exp Biol 2002;6:717-26.

5. DeLeve LD, Kaplowitz N. Mechanisms of drug induced liver diseases. Gastroenterol Clin N Am 1995;24:787-810.

6. Bhat $A D$, Bhat $S$. Indigenous drugs and liver diseases. Indian J Gastroenterol 1996;15:63-7.

7. Paget GE, Barnes JM. In: Evaluation of drug activities. Pharmacometrics. Lawrence DR, Bachrach AL, editors. Vol. 1. New York: Academic Press; 1964.

8. OECD (2000). Acute oral Toxicity - Acute oral toxic class method. Guideline 423, adopted 23.03.1996. In: Eleventh Addendum to the OECD guidelines for the Testing of Chemicals. Organisation for Economic Co-Operation and Development, Paris, June 2000.

9. Rao PGM, Rao SG, Kumar V. Effect of Hepatogard against carbontetrachloride induced liver damage in rats. Fitoterapia 1993;64:108-13.

10. Dwivedi Y, Rastogi R, Chander R, Sharma SK, Kapoor NK, Garg NK, et al. Hepatoprotective activity of Picroliv against carbontetrachloride induced liver damage in rats. Indian J Med Res 1990;92:195-200.

11. Kataria M, Singh LN. Hepatoprotective activity of Liv 52 and Kumaryasava on carbontetrachloride induced hepatic damage in rats. Indian J Exp Biol 1997;35:655-7. 
12. Sheweita SA, Abd El-Gabar M, Bastawy M. Carbon tetrachloride induced changes in the activity of Phase II drug metabolizing enzymes. Toxicology 2001;165:217-24.

13. Reitman S, Frankel S. A colorimetric method for the determination of SGOT and SGPT. Am J Clin Pathol 1957;28:56-63.

14. Kind PRN, Kings EJ. Estimation of plasma phosphatase by determination of hydrolysed phenol with antipyrine. J Clin Pathol 1954;7:322-30.

15. Ellaman GL. Tissue sulfhydryl group. Arch Biochem Biophys 1959;82:70-2.

16. Yagi K, Rastogi R. Assay for lipid peroxides in animal tissues by thiobarbituric acid reaction. Analytical Biochem 1979;95:351-8.

17. Jiang Zy, Hunt JV, Wolff SP. Ferrous ion oxidation in the presence of Xylenol orange for detection of lipid hydroxide in low-density lipoprotein. Anal Biochem 1992;202:384-9.

18. Kakkar P, Dass B, Visvanathan PN. A modified spectrophotometric assay of superoxide dismutase. Indian J Biochem 1972;197:588-90.
19. Sinha KA. Colorimetric assay of catalase. Anal Biochem 1972;47:389-94.

20. Lowry OH, Rosenberg NJ, Farr AL, Randall RJ. Protein measurement with Folin Phenol reagent. J Biol Chem 1951;193:265-75.

21. Prophet EB, Mills B, Arrington JB, Sobin LH. Laboratory Methods in Histotechnology. Washington DC: Armed Forces Institute of Pathology; 1992.

22. Bancroft JD, Stevens A, Dawson IMS. Theory and Practice of Histological T echniques. Edinburgh, London, New York. Churchill-Livingstone 1977.

23. Armitate P, Bregg G. In: Statistical methods in medical research. $2^{\text {nd }}$ ed. London: Blackwell Scientific Publications; 1985.

24. Johnson DE, Kroening C. Mechanism of early carbontetrchloride toxicity in cultured rat hepatocytes. Pharmacol Toxicol 1998;83:231-9.

25. Srivastava SP, Chen NO, Holtzman JL. The in vitro NADPH dependent inhibition by $\mathrm{CCl}$ of the ATP dependent calcium uptake of hepatic microsomes from male rats. Studies on the mechanism of inactivation of the hepatic microsomal calcium pump by the $\mathrm{CCl}$ radical. J Biol Chem 1990;265:8392-99.

\title{
SECOND NATIONAL WORKSHOP ON BASIC TECHNIQUES IN MOLECULAR BIOLOGY AND BIOINFORMATICS IN PHARMACOGENOMICS (Sponsored by ICMR)
}

\author{
Date: July 27th to August 3rd, 2005 \\ Venue: Pharmacogenomics Lab, Department of Pharmacology, \\ JIPMER, Pondicherry.
}

This workshop is jointly organized by JIPMER and VCRC, Pondicherry and partially funded by ICMR. It is intended for beginners in molecular biology and bioinformatics, with focus on 'Pharmacogenomics'. This workshop covers practical demonstrations and hands-on training in molecular biology techniques and bioinformatics pertaining to Pharmacogenomics. Lectures will be held on the elements of medical genetics, various techniques (simple to advanced) in Molecular Biology and the application of these techniques.

A total of 20 participants will be admitted preferably post-graduate students and Faculty members of Departments of Pharmacology and Allied Sciences.

The registration fee is $\mathbf{R s .} \mathbf{3 5 0 0 / -}$, which includes resource material, accommodation, food and half a day sight-seeing.

\section{Applications must reach on or before $4^{\text {th }}$ July, 2005.}

\section{For further information, please contact:}

\section{Dr. C. Adithan}

(Organizing Secretary)

Director Professor, Department of Pharmacology, JIPMER, Pondicherry 605006

E-mail: jipgene@yahoo.com. Tel: 0413-2272380 - 9 (10 lines) Ext. 3302. \& 3308,

Mobile: 98941-33903 